\title{
Characterization of Muscarinic Receptor Involvement in Human Ciliary Muscle Cell Function
}

\author{
IOK-HOU PANG ${ }^{1}$ SHUN MATSUMOTO, ${ }^{2}$ \\ ERNST TAMM,${ }^{3}$ and LOUIS DESANTIS ${ }^{1}$ \\ ${ }^{1}$ Glaucoma Research, Alcon Laboratories, Fort Worth, Texas \\ ${ }^{2}$ Department of Pharmacology, University of North Texas Health Science Center at Fort Worth, \\ Fort Worth, Texas \\ ${ }^{3}$ Anatomisches Institut der Universität Erlangen-Nürnberg, Erlangen, Germany
}

\begin{abstract}
Muscarinic agonist-induced contraction of the ciliary muscle is generally believed to increase aqueous outflow facility and effect accommodation. We used cultured human ciliary muscle cells as a model to study the muscarinic receptor subtype(s) involved in the contractile response of the muscle. Thus, a single cell contraction assay for these muscle cells was developed. And since agonist-induced contraction of smooth muscles is expected to involve the activation of phospholipase C (PLC), we also monitored the PLC activity in these cells. Carbachol caused contraction of the muscle cells in a dose-dependent and time-dependent manner with an estimated $\mathrm{EC}_{50}$ of $1.3 \mu \mathrm{M}$. The contractile effect of $100 \mu \mathrm{M}$ carbachol was antagonized by pretreatment of atropine $(1 \mu \mathrm{M})$ and 4DAMP (10 nM, antagonist selective for the $\mathrm{MI}$ and $\mathrm{M} 3$ receptors) but not by pirenzepine (10 $\mu \mathrm{M}$, antagonist selective for the M1 receptor), suggesting the involvement of the M3 but not the M1 muscarinic receptor. M3 receptor is also essential for the carbachol-induced PLC activation in the ciliary muscle cells, as indicated by the activity profiles of receptor subtype selective antagonists. For example, the stimulative effect of carbachol $\left(\mathrm{EC}_{50}=20 \mu \mathrm{M}\right)$ was antagonized by pirenzepine $(\mathrm{pKi}=6.8)$, HHSiD $(\mathrm{pKi}=$ 7.6), 4DAMP ( $\mathrm{pKi}=9.5$ ) and methoctramine $(\mathrm{pKi}<6)$. Thus, these results indicate that an M3-like receptor subtype is essential in mediating the muscarinic agonists induced functional changes, such as PLC activation or muscle contraction, in the ciliary muscle.
\end{abstract}

\section{INTRODUCTION}

Muscarinics, such as pilocarpine and carbachol, have been used topically as ocular hypotensive agents for more than a century (1-3). They lower intraocular pressure (IOP) presumably by contracting the ciliary muscle (4), which in turn increases the trabecular outflow of aqueous humor.

Topical administration of cholinergic agonists is safe. Due to the low systemic concentration of the drug after topical uses, systemic side effects rarely occur (3). However, ocular side effects of muscarinic agonists are common, which limits the acceptability of these compounds. Adverse reactions to pilocarpine and carbachol include miosis (due to the contraction of the iris sphincter), myopia (contraction of the ciliary muscle), temporal and supraorbital headache (supposedly 
secondary to the contraction of the ciliary muscle). Attempts, such as the exploitation of pharmacokinetic properties of the compounds, have been made to minimize these side effects, with only limited success. However, there is recent evidence suggesting that separation of the IOP-lowering effect and ocular side effects of cholinergics is feasible. For example, aceclidine, another muscarinic agonist, is as effective and potent as pilocarpine at lowering IOP in humans, but is much more potent as a miotic and does not produce much accommodation (5-8). In the monkey, aceclidine also increases facility of aqueous outflow with minimal accommodative effect (9). Furthermore, in the monkey, the increase in outflow facility produced by pilocarpine was reversed by atropine in two phases, a fast phase and a slow one. Yet the reversal of accommodation exhibited only a fast phase (10). This separation of muscarinic effects could be explained by the presence of different muscarinic receptor subtypes, each of which mediates different actions of the agonists.

Indeed, during the last several years, messenger RNAs of five muscarinic receptor subtypes were discovered $(11,12)$. They are named $\mathrm{ml}$ to $\mathrm{m} 5$, in which $\mathrm{m} 1$, $\mathrm{m} 2$ and $\mathrm{m} 3$ correspond to the $\mathrm{M} 1, \mathrm{M} 2$ and $\mathrm{M} 3$ receptor subtypes that were defined by affinity profiles of selective antagonists. Since both carbachol and pilocarpine are nonspecific among the five receptors, it is possible, as stated before, that the IOP-lowering effect and the ocular side effects of muscarinics involve different receptor subtypes. If this hypothesis is true, then a selective agonist properly chosen could be highly effective in lowering IOP and have minimal miotic or accommodative actions. Initial steps in testing this hypothesis are to define the distribution of the various receptor subtypes in the eye and to confirm the involvement of the receptors in the various ocular actions of muscarinic agonists. Several published studies tried to address these issues (13-17). In this report we used the cultured human ciliary muscle cells and attempted to elucidate the muscarinic receptor subtype that mediates the carbachol-induced contraction of the muscle cells as well as the activation of phospholipase C (PLC).

\section{METHODS}

\section{Cell Culture}

Human ciliary muscle cells were isolated and characterized as described earlier (18). The cells were cultured at $37^{\circ} \mathrm{C}$ and $5 \% \mathrm{CO}_{2}$, in Dulbecco's modified Eagle's medium (Gibco BRL, Grand Island, NY) with $10 \%$ fetal calf serum (Hyclone, Logan, UT), supplemented with $4 \mathrm{mM} \mathrm{L-glutamine} \mathrm{(Gibco} \mathrm{BRL)} \mathrm{and} 50 \mu \mathrm{g} / \mathrm{ml}$ gentamicin (Gibco BRL). Cells were subcultured following trypsinization. They were shown to be free of mycoplasma contamination (assayed by MycoTect Mycoplasma Detection Kit, Gibco BRL).

\section{Cel1 Contraction Assay}

Single cell contraction assay of the ciliary muscle cells were performed according to the procedure of Pang et al (19). Briefly, on the day of study, the cells (of passages 8 to 12) were partially detached from the plastic cultured dish (Costar, Cambridge, MA) by replacing the medium with a nonenzymatic cell dissociation buffer (catalog no. C-5914, Sigma, St Louis, MO) and incubated at $37^{\circ} \mathrm{C}$ for 30-40 min. Carbachol (Research Biochemicals Inc., Natick, MA) was then added. In some experiments, an antagonist such as atropine sulfate (Sigma), Pirenzepine HCl (Research Biochemicals Inc.) or 4-diphenylacetoxy-N-methylpiperidine methiodide (4DAMP, Research Biochemicals Inc.) was added $5 \mathrm{~min}$ before the addition of carbachol. Photomicrographs were taken at time intervals throughout the experiments. The cross-sectional surface areas of the cells were obtained by projecting the cell images of each photograph through a video camera onto a monitor screen of a personal computer. The cell images were then manually outlined, and the surface areas enclosed by the outlines were quantified using an image-analysis software (BioQuant, $R \& M$ Biometrics, Inc., Nashville, TN). A decrease in crosssectional surface area of the cells was interpreted as an indication of cell contraction. To normalize the changes, relative areas of the cells were used. The 
relative area of a cell was defined as the surface area at the indicated time point divided by the surface area at time 0 of the same cell.

\section{Phospholipase C Assay}

For PLC activity assay, the ciliary muscle cells (of passages 10 to 14) were cultured on 24-we11 plates (confluent monolayer, 7 to $8 \times 10^{5}$ cells/we11) and incubated with $\left[{ }^{3} \mathrm{H}\right]$ myoinositol (Amersham, Arlington Heights, IL, $5 \mu \mathrm{Ci} / \mathrm{ml} /$ well) in a serum-free mixture $(1: 1)$ of Dulbecco's modified Eagle's medium: nutrient mixture F12 for two days. On the day of study, free radioactive inositol was removed by rinsing the cells four times with $1 \mathrm{ml}$ serum-free medium containing $10 \mathrm{mM} \mathrm{LiCl}$ (Mallinckrodt, Paris, KY). Agonists were added $10 \mathrm{~min}$ later. In some studies, antagonists were added 5 min prior to agonists. At the indicated time after the agonist was added, the reaction was stopped by replacing the medium with $0.5 \mathrm{ml}$ of $5 \%$ perchloric acid (Baker, Philipsburg, NJ). Samples were placed on ice for at least $10 \mathrm{~min}$. The perchloric acid was removed from the cell lysate by extraction with $2 \mathrm{ml} \mathrm{1:1}$ mixture of 1,1,2-trichloro-trifluoro-ethane (Sigma):tri-n-octylamine (Sigma). After extraction, the aqueous layer was loaded onto $1 \mathrm{~m} 1 \mathrm{columns}$ of formate-equilibrated BioRad AG 1x8 anion exchange resin (BioRad, Richmond, CA). The columns were washed with $10 \mathrm{ml}$ of water, followed by $8 \mathrm{ml}$ of $50 \mathrm{mM}$ formic acid (Sigma). The bound inositol phosphates were eluted with $4 \mathrm{ml}$ of $1.2 \mathrm{M}$ ammonium formate (Sigma) in $0.1 \mathrm{M}$ formic acid and the incorporated tritium was monitored by scintillation counting. In recent experiments, this assay procedure was simplified such that the reaction was stopped by replacing the cell medium with $0.5 \mathrm{ml}$ of 50 $\mathrm{mM}$ formic acid instead of perchloric acid. The cell lysate was then directly loaded onto the anion exchange column and eluted as described. The two assay procedures generated similar results.

\section{Materials}

Other compounds, such as p-fluoro-hexahydro-sila-difenidol (HHSiD), methoctramine $\mathrm{HCl}$, oxotremorine-M, pilocarpine $\mathrm{HCl}$ and pirenzepine $2 \mathrm{HCl}$ were obtained from Research Biochemicals Inc. Aceclidine was obtained from Alcon, Ft Worth, TX.

\section{RESULTS}

\section{Ce11 Contraction}

As shown in Figure 1 , the cross-sectional surface areas of most of the human ciliary muscle cells decreased 5 and $10 \mathrm{~min}$ after carbachol (100 $\mu \mathrm{M}$ ) treatment. No significant change in cell area was observed during the 5 -min period before the agonist was added. This change in cell surface area was interpreted as an indication of contraction. The cellular contraction was obvious within 1 min of carbachol treatment, and the surface area stabilized at approximately $10 \mathrm{~min}$ after the application of the muscarinic agonist (19). This carbachol-induced contraction was dose dependent. As demonstrated in Figure 2A, $0.1 \mu \mathrm{M}$ of carbachol was ineffective in producing contraction of the muscle ce11s, whereas $1 \mu \mathrm{M}$ caused a partial contraction (ie, the area of the cells decreased to $70 \%$ of the initial surface area). Higher concentrations of carbachol induced additional contraction of the cells: 10 and $100 \mu \mathrm{M}$ of the agonists reduced the cells to $40-50 \%$ of their original sizes. A dose-response curve could be constructed by plotting the relative areas of the cells $10 \mathrm{~min}$ after carbachol treatment versus the concentration of carbachol used (Fig. 2B). The effective dose of carbachol for $50 \%$ of the maximal effect was estimated to be 1-3 $\mu \mathrm{M}$. The carbachol-induced contraction was apparently mediated by muscarinic cholinergic receptors. Pilocarpine, another muscarinic agonist, also caused the isolated ciliary muscle cells to contract (relative area at $10 \mathrm{~min}, 60 \pm 5 \%$ [mean \pm SEM, $n=7$ ] after $0.1 \mathrm{mM}$ pilocarpine treatment). Furthermore, the effect of $1 \mathrm{mM}$ carbachol was completely blocked by pretreatment of 


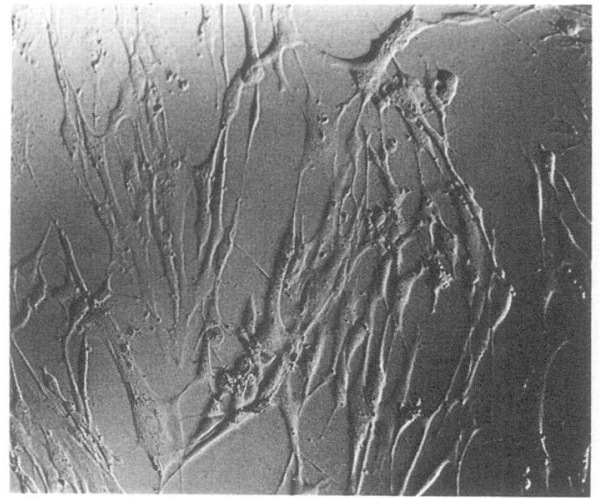

5 min before carbachol

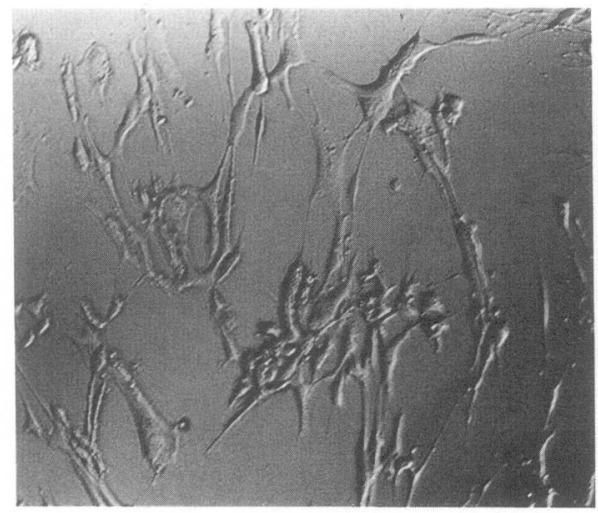

5 min after 100 uM carbachol

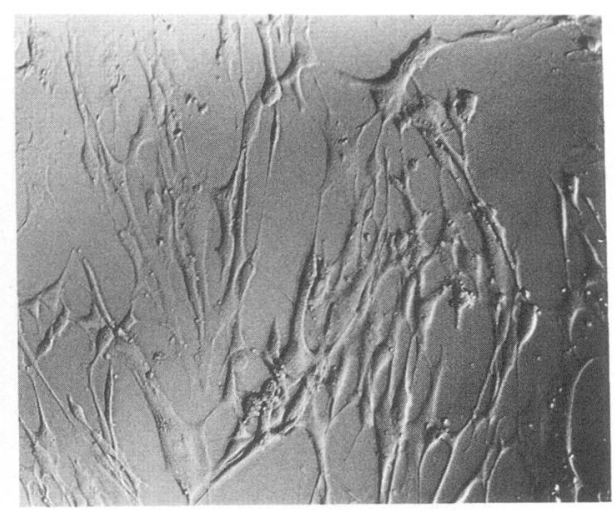

$10 \mathrm{sec}$ before carbachol

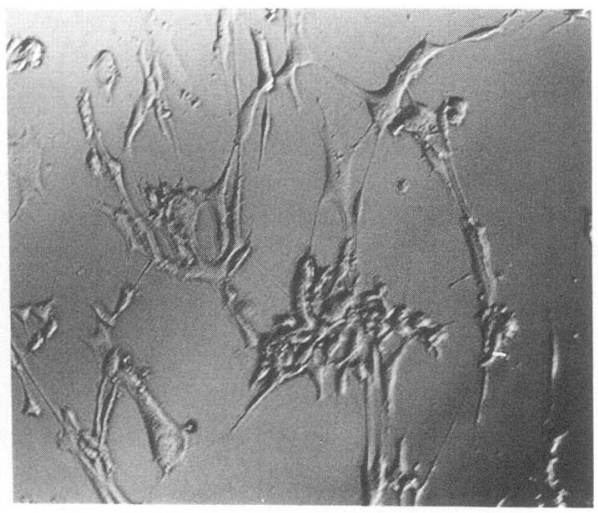

10 min after $100 \mathrm{uM}$ carbachol

FIGURE 1. Photomicrographs of human ciliary muscle cells during contraction induced by carbachol.

the cells with $1 \mu \mathrm{M}$ of atropine, a muscarinic antagonist (data not shown).

To clarify the involvement of the muscarinic receptor subtypes in the induction of contraction, receptor-selective antagonists were used to block the effect of carbacho1. 4DAMP, an antagonist selective for both M1 and M3 receptor subtypes, was very potent in preventing the carbachol-induced contraction (Fig. 3). Thus, pretreatment of the cells for $5 \mathrm{~min}$ with 0.1 nM 4 DAMP completely blocked the contractile effect of $10 \mu \mathrm{M}$ of carbachol but not that of $100 \mu \mathrm{M}$ or $1 \mathrm{mM}$ of carbachol (Fig. 3B). Effects of higher concentrations of carbachol were antagonized by increasing amounts of 4DAMP (Fig. 3C and 3D). Dose response relationship of carbachol in the presence of various concentrations of 4DAMP summarizes these results (Fig. 5, upper pane1). It is obvious that pretreatment of 4DAMP (0.1 to 10 $n M$ ) caused sequential rightward shifts of the potency of carbachol, indicating that 4DAMP is a potent and competitive antagonist for the muscarinic effect. The pA 2 calculated (according to ref. 20) from the observed shifts of the carbachol potency is 10.5. Since 4DAMP is an antagonist for both the Ml and M3 receptor subtypes, it is necessary to further differentiate the involvement of the two receptor subtypes. Pirenzepine is another potent muscarinic antagonist. At low concentrations, it is selective for the $\mathrm{M} 1$ receptor ( $\mathrm{pKi}=8)(11)$, whereas at higher concentrations (100 $\mathrm{nM}$ or higher), it also binds significantly to other muscarinic receptors and thus becomes nonselective. In the isolated human ciliary muscle cells, pirenzepine, at 

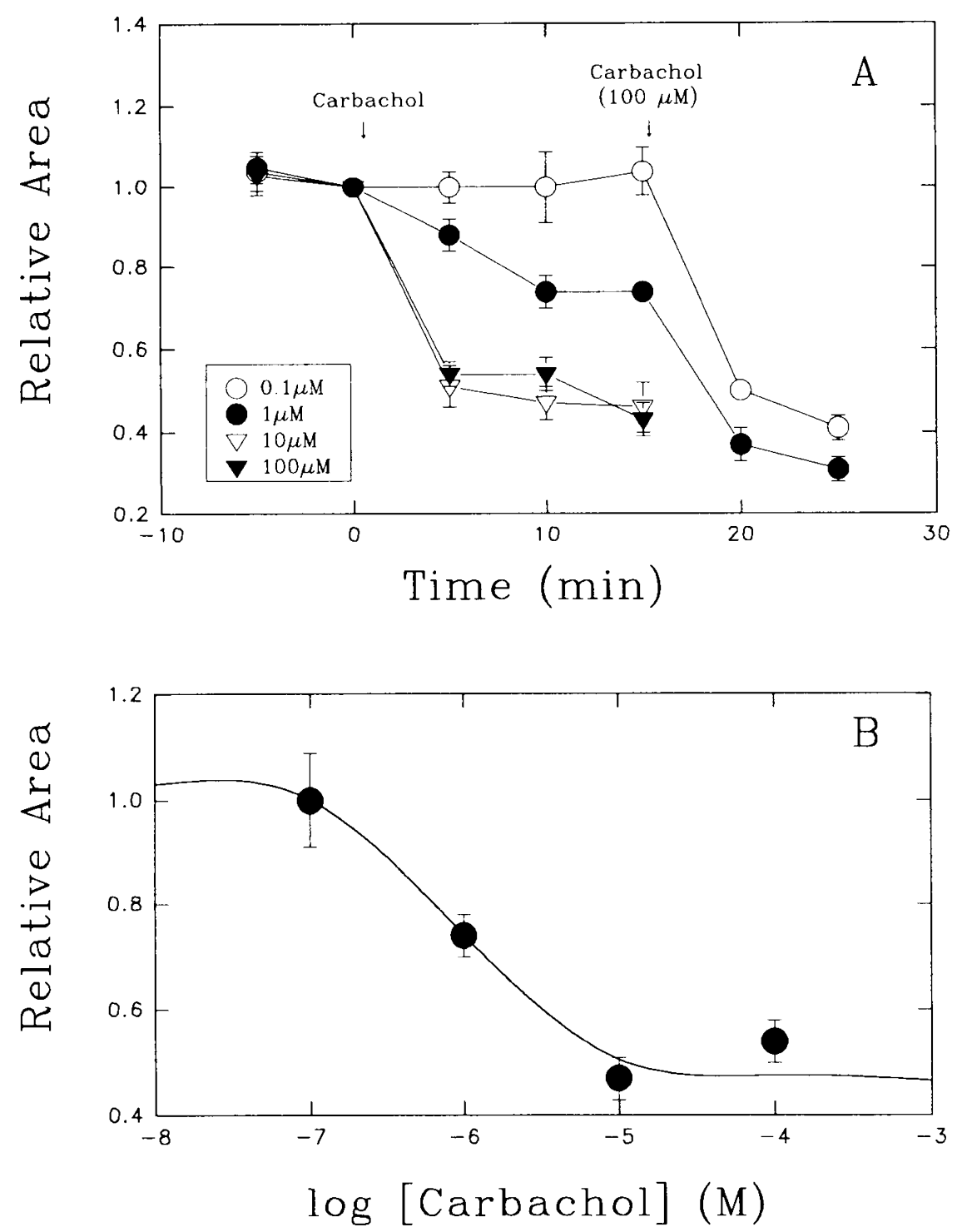

FIGURE 2. Effects of various doses of carbachol on ciliary muscle cell contraction. (A) Time courses of changes. Symbols represent the mean \pm SEM of seven cells at each dose. At $15 \mathrm{~min}$, carbachol $(100 \mu \mathrm{M})$ was added to some of the samples to demonstrate their full contraction capability. (B) Dose-response curve of carbachol. The relative areas at $10 \mathrm{~min}$ after carbachol treatment are presented here. Symbols represent the mean \pm SEM of seven cells. Reprinted with permission from ref. 19 .

concentrations 10,000 fold higher than that of 4DAMP, was effective in blocking the contraction induced by carbachol (Fig. $4 \& 5$, lower panel). The calculated $\mathrm{pA}_{2}$ for pirenzepine in this assay is 7.2 , indicating that an $M 1$ receptor was not essential in mediating the carbachol action.

\section{Phospholipase C Activity}

In smooth muscle cells, contraction can be a result of activation of PLC by 

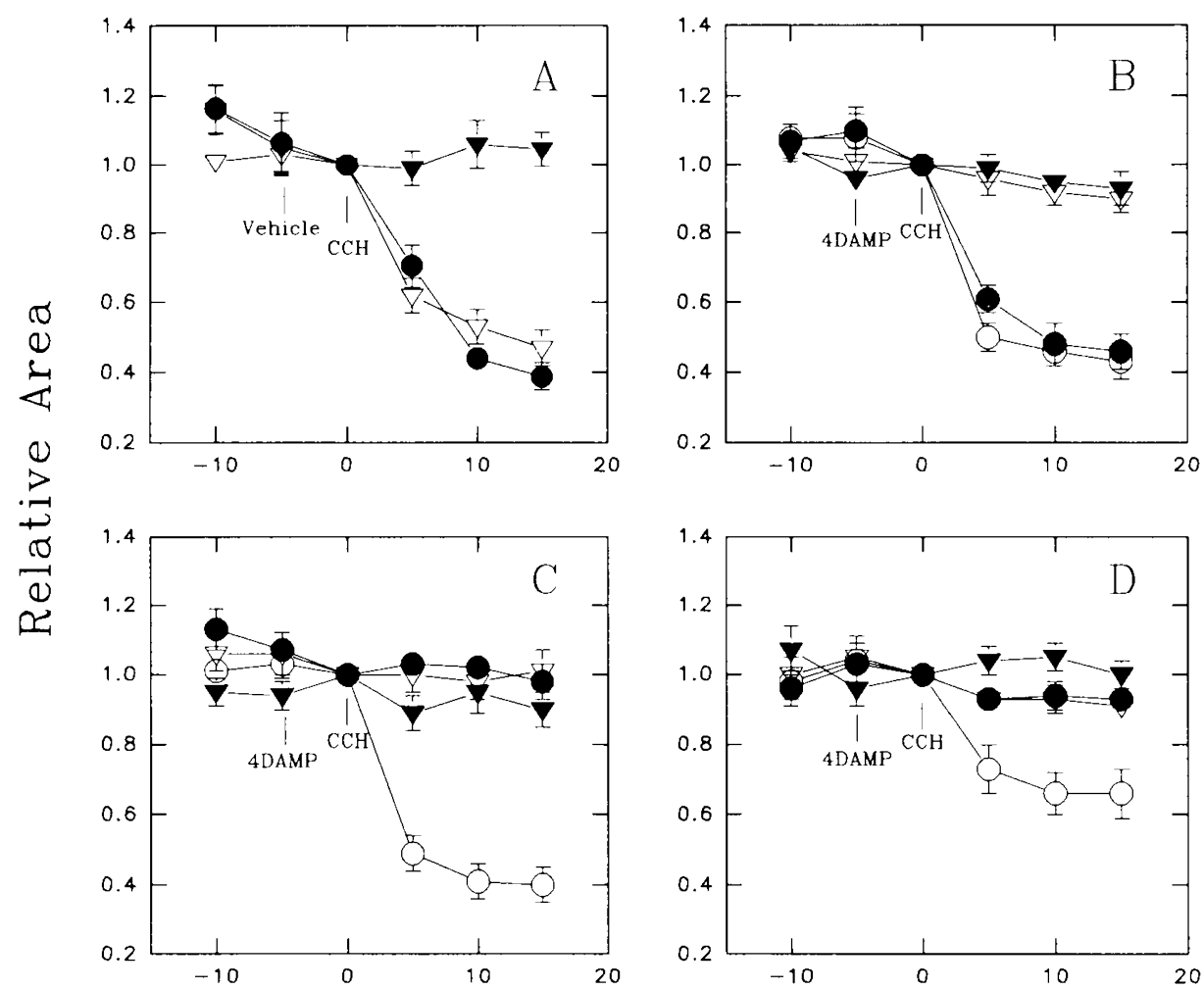

Time $(\min )$

FIGURE 3. Effects of 4DAMP on the contractile action of carbachol (CCH). At the indicated time points, cells were pretreated with vehicle or 4DAMP before the addition of carbachol. The pretreatments were vehicle (A), $0.1 \mathrm{nM}$ 4DAMP (B), $1 \mathrm{nM}$ 4DAMP (C) or $10 \mathrm{nM}$ 4DAMP (D). Dosages of carbachol used were $0 \mu \mathrm{M}$ (closed triangles), $10 \mu \mathrm{M}$ (open triangles), $100 \mu \mathrm{M}$ (closed circles) and $1 \mathrm{mM}$ (open circles). Each symbol represents mean relative area \pm SEM of seven cells.

agonists. Consequently, the effects of muscarinic agonists on PLC in these cells were tested. Carbachol $(100 \mu \mathrm{M})$ treatment activated the PLC for at least two hours as indicated by the continuous accumulation of inositol phosphates (data not shown). During this period, no significant desensitization of the receptor or depletion of the enzyme substrate was detected. Therefore, for the sake of convenience, one hour was chosen as the standard incubation time for the following studies. Muscarinic agonists, such as carbachol, oxotremorine-M, pilocarpine and aceclidine, stimulated the production of inositol phosphates in a dose dependent manner. Typical doseresponse curves are shown in Figure 6. Carbachol ( $1 \mathrm{mM}$ ) increased the accumulation of inositol phosphates in human ciliary muscle cells by approximately 10 fold from a basal level of $439 \pm 67 \mathrm{cpm} /$ well (mean \pm SEM from 10 duplicated studies) to 4633 $\pm 593 \mathrm{cpm} /$ well. Similar maximal stimulation was also seen with oxotremorine-M, another full agonist of the muscarinic receptor. Pilocarpine and aceclidine are partial agonists of the muscarinic agonist, such that their maximum effects are only fractions of that of a full agonist. We also observed the same phenomenon in their stimulation of PLC in the ciliary muscle cells. Table 1 presents the mean calculated $E_{50}$ values and the maximal effects of these compounds in relation to that of carbachol. 

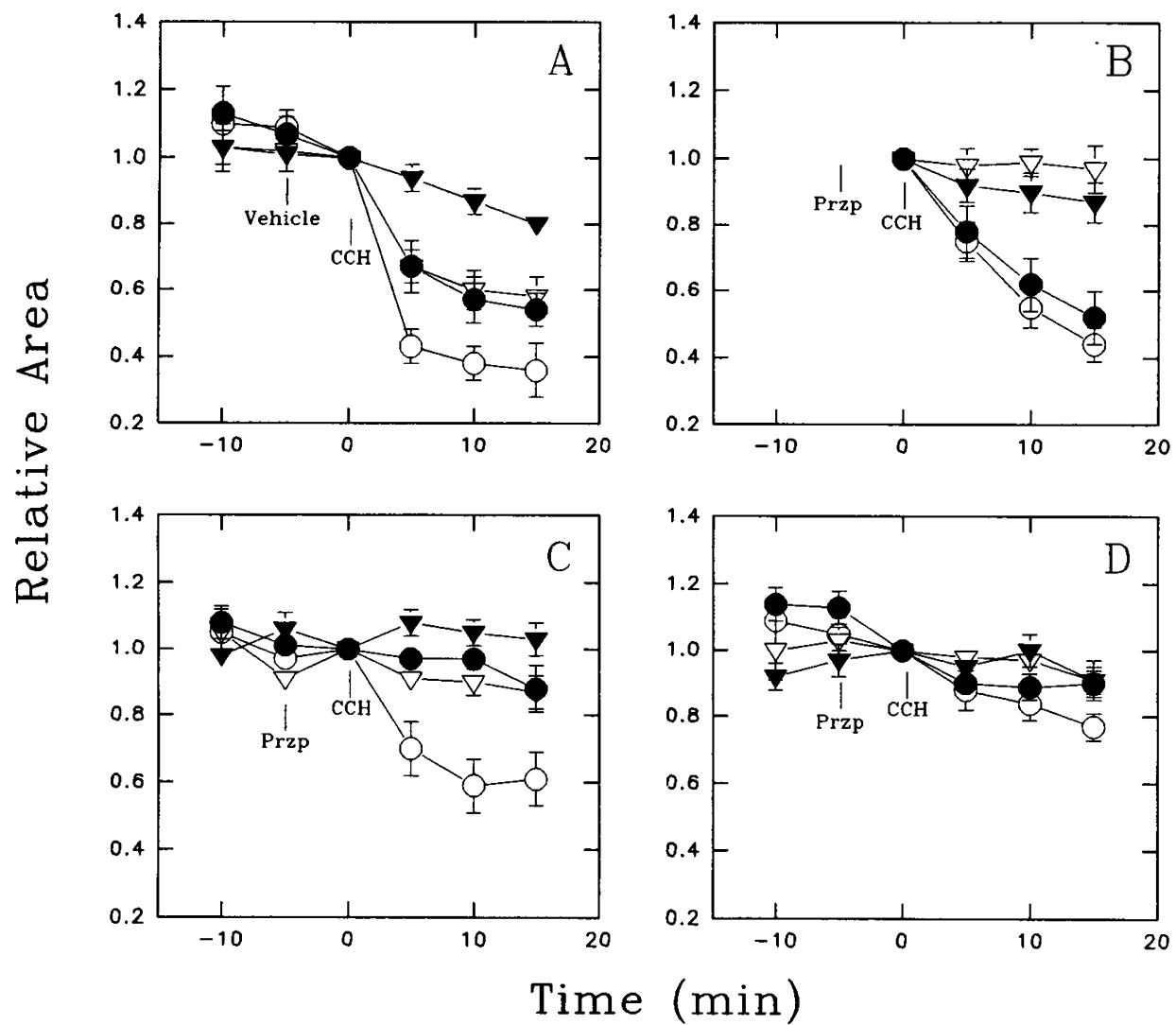

FIGURE 4. Effects of pirenzepine (przp) on the contractile action of carbachol $(\mathrm{CCH})$. At the indicated time points, cells were pretreated with vehicle or pirenzepine before the addition of carbachol. The pretreatments were vehicle (A), $1 \mu \mathrm{M}$ pirenzepine (B), $10 \mu \mathrm{M}$ pirenzepine (C) or $100 \mu \mathrm{M}$ pirenzepine (D). Dosages of carbachol used were $1 \mu \mathrm{M}$ (closed triangles), $10 \mu \mathrm{M}$ (open triangles), $100 \mu \mathrm{M}$ (closed circles) and $1 \mathrm{mM}$ (open circles). Each symbol represents mean relative area \pm SEM of seven cells.

To clarify the involvement of the muscarinic receptor subtypes in the activation of PLC, the following receptor-selective antagonists were used to block the effect of carbachol: pirenzepine, selective for the M1 receptor subtype; methoctramine, selective for M2; HHSiD, selective for M3; 4DAMP, for both M1 and M3; and atropine, a nonspecific antagonist. Figure 7 shows typical inhibition curves for some of the antagonists tested. The inhibition coefficient (Ki) of each compound was calculated with the equation: $\mathrm{Ki}=\mathrm{IC}_{50} /\left(1+[\right.$ carbachol $] /\left(\mathrm{EC}_{50}\right.$ of carbachol)) (21). Results are presented in Table 2. It is clear that the most potent subtypeselective antagonists in preventing the carbachol-induced PLC activation were 4DAMP and HHSiD, suggesting that the M3 receptor subtype was essential in mediating the muscarinic effect in the ciliary muscle cells.

\section{DISCUSSION}

In the cultured human ciliary muscle cells, muscarinic cholinergic agonists, such as carbachol, at concentration as high as $1 \mathrm{mM}$, did not affect the activities of nucleotide cyclases though adenylyl and guanylyl cyclase activities were detected 

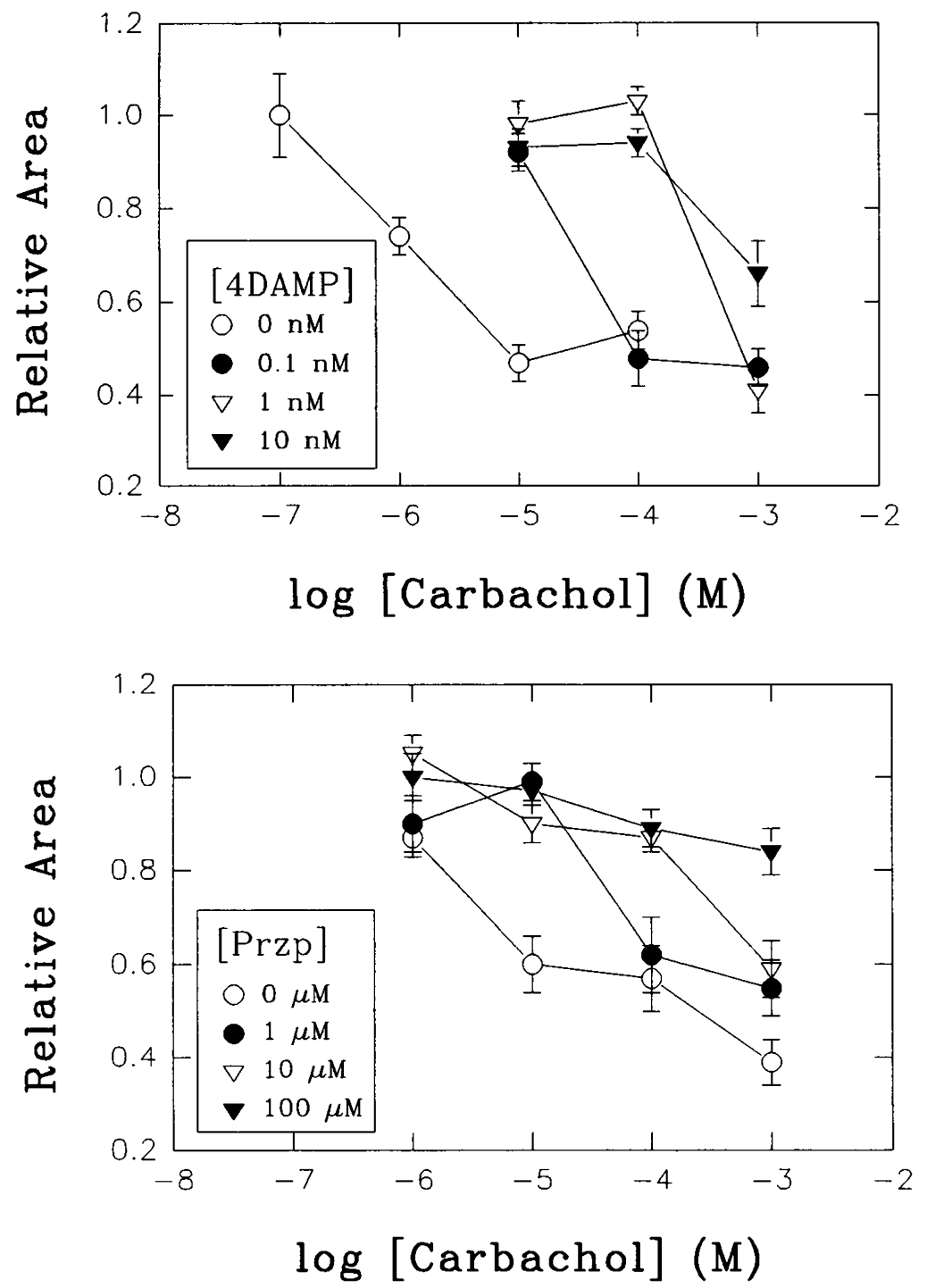

FIGURE 5. Dose response relationship of carbachol in the presence of 4-DAMP (upper panel) or pirenzepine (lower pane1). Cells were pretreated with different concentrations of 4-DAMP or pirenzepine for $5 \mathrm{~min}$ before the addition of carbachol. The relative areas at $10 \mathrm{~min}$ after carbachol treatment are presented here. Bars represent mean \pm SEM of seven cells.

in these cells as indicated by the stimulation induced by isoproterenol or sodium nitroprusside, respectively (unpublished observation). Instead, muscarinics activated PLC, increased intracellular concentration of calcium (unpublished observation) and caused cell contraction. We have reported here the results of their effects on PLC and contraction of these cells.

Carbachol decreased the cross-sectional surface area of the ciliary muscle cells. We interpreted this surface area change as an indication of cell contraction instead of volume change, because incubation of the cells in a hyperosmotic solution, a treatment known to cause shrinkage of the cell volume, only flattened the cells without significant decrease of the cross-sectional surface area (19). 


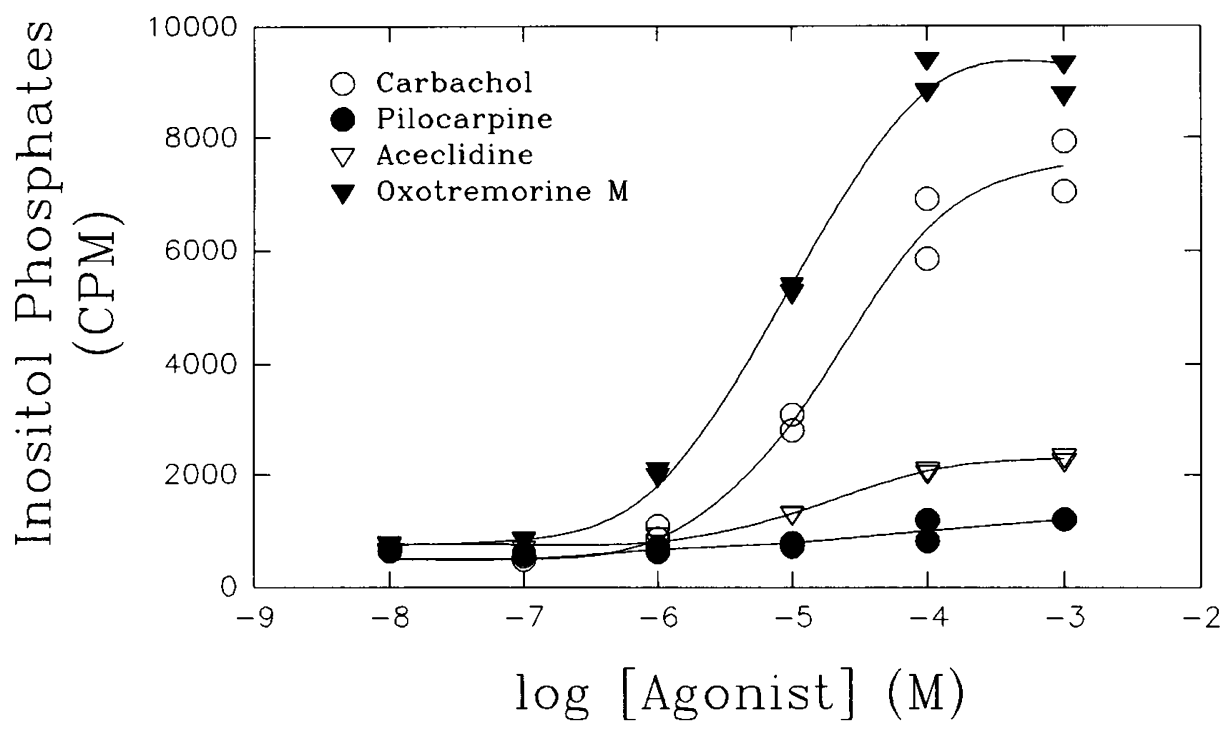

FIGURE 6. Dose response curves of muscarinic agonists on the activation of phospholipase $\mathrm{C}$ in the human ciliary muscle cells. Each symbol represents datum from a single sample.

TABLE 1

Activation of Phospholipase $C$ in The Human Ciliary Muscle Cell

\begin{tabular}{|c|c|c|c|c|}
\hline Agonist & $\mathrm{n}$ & mean $\mathrm{EC}_{50}$ & $\log \left[\mathrm{EC}_{50}\right] \pm \mathrm{SEM}$ & $\begin{array}{c}\mathrm{Max} * \pm \mathrm{SEM} \\
(\%)\end{array}$ \\
\hline Carbachol & 10 & $20.0 \mu \mathrm{M}$ & $-4.70 \pm 0.06$ & 100 \\
Oxotremorine-M & 3 & $6.9 \mu \mathrm{M}$ & $-5.15 \pm 0.03$ & $121 \pm 2$ \\
Aceclidine & 3 & $13.1 \mu \mathrm{M}$ & $-4.88 \pm 0.06$ & $31 \pm 1$ \\
Pilocarpine & 3 & $2.7 \mu \mathrm{M}$ & $-5.57 \pm 0.12$ & $13 \pm 1$ \\
\hline
\end{tabular}

*: Maximal effect of the agonists as compared to that of carbachol, which defines $100 \%$.

TABLE 2

Inhibition coefficients of Selective Muscarinic Antagonists on Carbachol-induced Phospholipase $C$ in The Human Ciliary Muscle Cells

\begin{tabular}{|c|c|c|}
\hline Antagonist & $\mathrm{n}$ & $\mathrm{pKi} \pm \mathrm{SEM}$ \\
\hline Atropine & 6 & $9.12 \pm 0.10$ \\
Pirenzepine & 7 & $6.76 \pm 0.05$ \\
4DAMP & 5 & $9.46 \pm 0.24$ \\
HHSiD & 7 & $7.57 \pm 0.11$ \\
Methoctramine & 2 & $<6.0$ \\
\hline
\end{tabular}




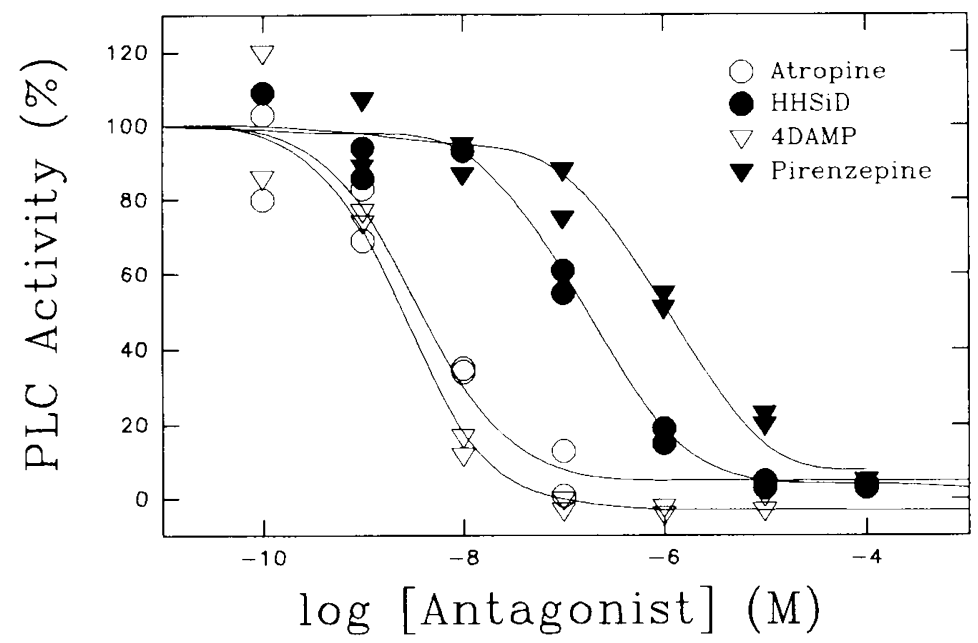

FIGURE 7. Inhibition curves of muscarinic antagonists on the carbachol-induced activation of phospholipase $C$ in the human ciliary muscle cells. The cells were pretreated with various concentrations of the antagonists before treated with 100 $\mu \mathrm{M}$ of carbachol. Each symbol represents a single sample.

Thus, carbachol induced contraction of ciliary muscle cells in a dose-dependent and time-dependent manner. Its effect was mimicked by pilocarpine and antagonized by atropine, indicating that the effect was mediated by a muscarinic cholinergic receptor. Similarly, the activation profile of PLC by the various agonists also agreed with published characteristics of muscarinic receptor-mediated actions.

In other smooth muscles, the activation of PLC by agonists can cause contraction. It is likely, yet unproven, that in the ciliary muscle cells, the contraction induced by muscarinic agonists is the result of the activation of PLC. The difference in the $E_{50}$ values of carbachol for the activation of PLC and contraction can be explained by the "spared receptor" concept, or, more accurately, the "spared second messenger" concept. Thus, activation of only a small fraction of the PLC may be sufficient to induce a full contraction response. Nevertheless, we cannot exclude the possibility that the two muscarinic actions were activated independently. Clarification awaits future studies.

Both the carbachol-induced changes in PLC activity and cell contraction were competitively inhibited by antagonists. The relative potency of the antagonists for PLC activation was 4DAMP $=$ atropine $>$ HHSiD > Pirenzepine $>$ methoctramine. Accordingly, in the contraction assay, 4DAMP was a much more potent antagonist than pirenzepine. Based on the affinity profiles of these selective antagonists, the M3 or an M3-like receptor subtype was essential in the carbachol-induced activation of PLC and cell contraction. These findings agree with the published data in that the M3 receptor is important for functions of the ciliary muscle. In the human ciliary muscle, by using autoradiography and in situ hybridization, Gupta et al showed that $\mathrm{m} 1 / \mathrm{M} 1$ and $\mathrm{m} 3 / \mathrm{M} 3$ receptor subtypes are present (14). The messenger RNA of the m3 receptor was detected by Northern blot in the cultured human ciliary muscle cells and post mortem tissue $(13,15)$. Furthermore, WoldeMussie et al (17) demonstrated that the muscarinic binding sites in these cells were most 1ikely M3 receptors and, similar to our findings, the muscarinic agonist-induced PLC activation was mediated by an M3-1ike receptor. Interestingly, the $\mathrm{m} 3 / \mathrm{M} 3$ receptor is also shown to be the most common muscarinic receptor subtype in the iris sphincter $(14,17)$, implying that this receptor likely mediates the muscarinic agonist-induced miosis. Indeed, Gabelt and Kaufman (16) demonstrated that in the perfused monkey eye, 4DAMP was the most potent antagonist in blocking the increase in aqueous outflow facility, accommodation and miosis caused by pilocarpine, showing that an M3-like receptor is essential in all of the actions of pilocarpine. Thus, it appears that the M3 
receptor mediates muscarinic agonist-induced contractions of both the iris sphincter and the ciliary smooth muscles. If it is proven true, separation of the IOPlowering effect and the ocular side effects of muscarinic compounds by using receptor subtype selective agonists will be theoretically impossible. This conclusion cannot reconcile with findings that aceclidine has different potencies for miosis, accommodation and outflow facility (5-9). It may also contradict the apparent two-component mode of the pilocarpine-induced increase in aqueous outflow facility (10). A potential explanation is that structures, which express other receptor subtypes, besides the ciliary muscle are also involved in the cholinergicmediated aqueous outflow effects. Clarification of this hypothesis requires future studies on other ocular tissues, such as the trabecular meshwork, and in vivo experiments using receptor subtype-selective agonists when they become available.

\section{ACKNOWLEDGEMENTS}

We thank Debra L. Shade and Peggy E. Magnino for superb technical assistance.

\section{REFERNCES}

1. Nardin, G.F., Zimmerman, T.J., Zaita, A.H., and Felts, K. Ocular cholinergic agents. In The glaucomas, Ritch, R., and Shields, M.B., eds. C.V. Mosby, St Louis, 1989, p. 515-521.

2. Hoskins, H.D., and Kass, M.A. In Becker-Shaffer's diagnosis and therapy of the glaucomas. C.V. Mosby, St Louis, 1989, p. 420-434.

3. Liopold, I.H. The use and side effects of cholinergic agents in the management of intraocular pressure. In Glaucoma: Applied pharmacology in medical treatment. Drance, S.M., and Neufeld, A.H, eds. Grune \& Stratton, Orlando, 1984 , p. $357-393$.

4. Bi11, A. Aqueous humor dynamics in monkeys. Exp. Eye Res.. 11:195-206, 1971 .

5. Lieberman, T.W., and Leopold, I.H. The use of aceclidine in the treatment of glaucoma. Its effect on intraocular pressure and facility of aqueous humor outflow as compared to that of pilocarpine. Am. J. Ophthalmo1.. 64:405-415, 1967 .

6. Romano, J.H. Double-blind cross-over comparison of aceclidine and pilocarpine in open-angle glaucoma. Br. J. Ophthalmol.. 54:510-521, 1970.

7. Fechner, P.U., Teichman, K.D., and Weyrauch, W. Accommodative effects of aceclidine in the treatment of glaucoma. Am. J. Ophthalmo1.. 79:104-106, 1975.

8. Keren, G., and Treister, G. Effect of aceclidine ( + ) isomer and pilocarpine on the intraocular pressure decrease and the miosis in glaucomatous eyes. Effect on accommodation in normal eyes of young subjects. Ophthalmologica, $180: 181-187,1980$.

9. Erickson-Lamy, K.A., and Schroeder, A. Dissociation between the effect of aceclidine on outflow facility and accommodation. Exp. Eye Res.. 50:143-147, 1990 .

10. Bàràny, E.H. The mode of action of pilocarpine on outflow resistance in the eye of a primate (Cercopithecus ethiops). Invest. Ophthalmol.. 1:712-727, 1962 .

11. Birdsall, N., Buckley, N., Doods, H., et al. Nomenclature for muscarinic 
receptor subtypes recommended by symposium. Trends Pharmacol. Sci. 10(suppl.):vii, 1989.

12. Goyal, R.K. Muscarinic receptor subtypes: physiology and clinical implications. New England J. Med., 15:1022-1028, 1989.

13. Erickson-Lamy, K.A., Chen, M.C., and Hernandez, M.R. Expression of muscarinic receptor messenger RNA in cultured ciliary muscle cells. Invest. Ophthalmol. Vis. Sci.. 32:833, 1991.

14. Gupta, N., Prasad, S., McAllister, R., Drance, S.M., and Cynader, M.S. The distribution of $M 3$ muscarinic receptor subtype and $m 3$ messenger RNA in human ocular structures. Soc. Neurosci. Abs.. 17:587, 1991.

15. Bogardus, A.M., Feldmann, B.J., WoldeMussie, E., and Gil, D.W. Muscarinic receptor subtypes in human eye. Soc. Neurosci. Abs.. 17:587, 1991.

16. Gabelt, B.T., and Kaufman, P.L. Inhibition of outflow facility and accommodative and miotic responses to pilocarpine in rhesus monkeys by muscarinic receptor subtype antagonists. J. Pharmacol. Exp. Ther.. 263:1133$1139,1992$.

17. WoldeMussie, E., Feldmann, B.J., and Chen, J. Characterization of muscarinic receptors in cultured human iris sphincter and ciliary smooth muscle cells. Exp. Eye Res.. 56:385-392, 1993.

18. Tamm, E., Flügel, C., Baur, A., and Lütjen-Drecoll, E. Cell cultures of human ciliary muscle: Growth, ultrastructural and immunocytochemical characteristic. Exp. Eye Res... 53:365-387, 1991.

19. Pang, I.-H., Shade, D.L., Tamm, E., and DeSantis, L. Single-cell contraction assay for human ciliary muscle cells: effect of carbachol. Invest. Ophthalmol. Vis. Sci.. 34:1876-1879, 1993.

20. Arunlakshana, O., Schild, H.O. Some quantitation uses of drug antagonists. Br. J. Pharmacol., 14:48-58, 1959.

21. Craig, D.A. The Cheng-Prusoff relationship: something lost in the translation. Trends Pharmaco1. Sci.., 14:89-91, 1993.

22. Pang, I.-H., Shade, D., Tamm, E., and DeSantis, L. Contraction of human ciliary muscle cell induced by muscarinic agonists. Invest. Ophthalmol. Vis. Sci.. 33:731, 1992.

23. Matsumoto, S., Magnino, P.E., Miggans, S.T., Shade, D.L., DeSantis, L., Pang, I-H. Receptor-mediated activation of phospholipase $C$ in cultured nontransformed and transformed human ciliary muscle cells. Ocular Cell Mol. Biol. Sym. Abs... 1:26, 1992 .

Received: August 11, 1993

Accepted for Publication: September 21, 1993

Reprint Requests: Iok-Hou Pang, Ph.D.

Alcon Laboratories, R3-24

6201 South Freeway

Fort Worth, Texas 76134

U.S.A.

Portions of this manuscript were published in references $19,22 \& 23$. 


\section{This article has been cited by:}

1. Clare Johnson, Janet Smereck. 2012. Unilateral Mydriasis Due to a Topical "Anti-sweat" Preparation. The Journal of Emergency Medicine . [CrossRef]

2. F Yasui, M Miyazu, A Yoshida, K Naruse, A Takai. 2008. Examination of signalling pathways involved in muscarinic responses in bovine ciliary muscle using YM-254890, an inhibitor of the Gq/11 protein. British Journal of Pharmacology 154:4, 890-900. [CrossRef]

3. Jennifer C. Chen, Katrina L. Schmid, Brian Brown. 2003. The autonomic control of accommodation and implications for human myopia development: a review. Ophthalmic and Physiological Optics 23:5, 401-422. [CrossRef]

4. John S. Kennedy, Frank P. Bymaster, Leslie Schuh, David O. Calligaro, George Nomikos, Christian C. Felder, Mark Bernauer, Bruce J. Kinon, Robert W. Baker, Donald Hay, H. John Roth, Martin Dossenbach, Christopher Kaiser, Charles M. Beasley, John H. Holcombe, Mark B. Effron, Alan Breier. 2001. A current review of olanzapine's safety in the geriatric patient: from pre-clinical pharmacology to clinical data. International Journal of Geriatric Psychiatry 16:S1, S33-S61. [CrossRef]

5. G W Nietgen, J Schmidt, L Hesse, C W Hönemann, M E Durieux. 1999. Muscarinic receptor functioning and distribution in the eye: Molecular basis and implications for clinical diagnosis and therapy. Eye 13:3a, 285-300. [CrossRef]

6. XUN ZHANG, ALISON SCHROEDER, KRISTINE A. ERICKSON. 1999. Effect of Continuous Administration of a Cholinergic Agonist on [3H]4-DAMP Binding and m3 mRNA Expression in Cultured Human Ciliary Muscle Cells. Journal of Ocular Pharmacology and Therapeutics 15:2, 153-163. [Abstract] [Full Text PDF] [Full Text PDF with Links]

7. HITOSHI ISHIKAWA, LOUIS DeSANTIS, POPAT N. PATIL. 1998. Selectivity of Muscarinic Agonists Including ( \pm )-Aceclidine and Antimuscarinics on the Human Intraocular Muscles. Journal of Ocular Pharmacology and Therapeutics 14:4, 363-373. [Abstract] [Full Text PDF] [Full Text PDF with Links] 